\title{
Tumor-Related Protein
}

National Cancer Institute

\section{Source}

National Cancer Institute. Tumor-Related Protein. NCI Thesaurus. Code C54672.

Normal proteins that, when altered or inappropriately expressed, contribute to tumor cell growth, proliferation, progression or metastasis. 